\title{
Pancreatic Reg/pancreatic stone protein (PSP) gene expression does not correlate with beta-cell growth and regeneration in rats
}

\author{
F. E.Smith ${ }^{1}$, S. Bonner-Weir ${ }^{1}$, J. L. Leahy ${ }^{1}$, M. J. Laufgraben ${ }^{1}$, Y. Ogawa ${ }^{1}$, K. M. Rosen ${ }^{2}$, L. Villa-Komaroff ${ }^{2}$ \\ ${ }^{1}$ Research Division, Joslin Diabetes Center, Boston, Massachusetts, USA \\ ${ }^{2}$ Division of Neurosciences, Children's Hospital, Harvard Medical School, Boston, Massachusetts, USA
}

\begin{abstract}
Summary The Reg/pancreatic stone protein (PSP) gene is postulated to be an important regulator of pancreatic beta-cell growth. To investigate this hypothesis, we analysed the expression of the Reg/PSP gene following a $90 \%$ pancreatectomy and after chronic glucose infusion, two well-defined models of pancreatic beta-cell growth. There was a rapid induction of the Reg/PSP gene in the remnant pancreas after a $90 \%$ pancreatectomy in rats during the period of marked growth of the exocrine and islet tissue. However, a similar rapid, but smaller, induction of the Reg/PSP gene was observed in sham-operated
\end{abstract}

rats and in non-surgical control rats in which there was no enhanced pancreatic growth. Furthermore, there was no pancreatic Reg/PSP gene induction in a model of selective beta-cell growth, the chronic glucose-infused rat. Thus, it is unlikely that Reg/PSP is a beta-cell specific growth factor, even though the function of this important pancreatic gene is still unknown. [Diabetologia (1994) 37: 994-999]

Key words Pancreas, growth factors, gene expression, beta cells.
A pancreatic gene called Reg, encoding a 165-amino acid protein was isolated from a cDNA library derived from regenerating rat islets after partial pancreatectomy (Px) and daily nicotinamide injection [1]. Recently, a second distinct Reg gene (Reg II) with $76 \%$ amino acid homology to the Reg (I) gene was described in the mouse pancreas and in hyperplastic islets but not in normal islets [2]. The Reg gene described in the regenerating pancreatic islets was later found to be identical to an exocrine pancreatic gene which codes for pancreatic stone protein, PSP $[3,4]$, or pancreatic thread protein, PTP [4, 5 ]. This protein is a major secretory product in pancreatic juice and comprises $10-14 \%$ of the total se-

Received: 17 November 1993

and in revised form: 16 May 1994

Corresponding author: Dr. F. E. Smith, Research Division, Section of Islet Transplantation and Cell Biology, Joslin Diabetes Center, Boston, MA 02215, USA

Abbreviations: Px, Partial pancreatectomy; PSP, pancreatic stone protein. creted proteins. The function of Reg/PSP is unknown, but in the exocrine pancreas, it may inhibit calcium lithiasis $[6,7]$. Several studies have reported an association between enhanced Reg gene expression and changes in beta-cell volume [8] or thymidine incorporation in isolated islets [9] suggesting that this peptide may be an important regulatory protein for beta-cell growth. However, Reg/PSP mRNA or protein has generally been localized to the pancreatic acinar tissue, with no evidence of expression in islets $[8,10,11]$. Terazono et al. [12], reported the presence of Reg/PSP protein both in rat acinar cells and within insulin granules of beta-cells several weeks after nicotinamide treatment and Px suggesting that the Reg/PSP gene may be induced in proliferating beta-cells. While the site of pancreatic Reg/PSP synthesis remains controversial, Reg mRNA or protein has also been detected in a number of other normal tissues including gastric mucosa, kidney, small intestine, salivary duct epithelium, cutaneous eccrine glands, and epidermis [13, 14], developing human brain and pathological states such as Alzheimer's disease [15] and some colon and rectal tumours [4]. 
Although the functions of this protein in these tissues are unknown, it is speculated to play a role in regulation of cell growth $[13,15]$.

We have investigated the relationship between Reg/PSP gene expression and beta-cell growth in two well-characterized models of rat pancreatic growth, the $90 \% \mathrm{Px}[16,17]$ and the chronic glucose infused rat $[18,19]$. Since these rat models are associated with different patterns of pancreatic growth, mRNA from these animals was analysed for changes in Reg/PSP gene expression.

\section{Materials and methods}

Experimental animals. (90\% Px) Under sodium amytal anaesthesia, 100-g male Sprague-Dawley rats underwent a 90\% Px as previously described [16]. The pancreatic tissue was gently abraded from the blood vessels except for an anatomically well-defined portion bordered by the common pancreatic duct and the duodenum. In sham-operated rats, the pancreas was rubbed between the fingers but no tissue was removed. Pancreatic tissue was taken for RNA isolation from weightmatched, normal, non-operated animals and at 1,2, 3, 7 and 14 days after $P x$ or sham surgery. In this model, significant growth of both exocrine and endocrine tissue occurs by replication of pre-existing cells and by ductal proliferation and subsequent differentiation into exocrine and endocrine tissue [16, $17,20]$. Additional surgical controls were performed that mimicked steps in the Px and sham surgery but in which no pancreatic tissue was removed. Pancreatic RNA was isolated from these rats $24 \mathrm{~h}$ after the following treatments: intraperitoneal injection of $0.2 \mathrm{ml}$ of $0.9 \% \mathrm{NaCl}$, abdominal laparotomy and laparotomy with lysis of mesenteric connections to the coIon. To test the effects of sodium amytal anaesthesia, pancreatic RNA was isolated 24 , and $48 \mathrm{~h}$ after a single intraperitoneal injection of sodium amytal (Eli Lilly, Indianapolis Ind., USA; $0.1 \mathrm{gm} / \mathrm{kg}$ body weight). Additional non-surgical controls included normal weight-matched rats subjected to handling stress by confining the rat in an acrylic restraint cage 34 times during $1 \mathrm{~h}$ before killing $24 \mathrm{~h}$ later.

Chronic glucose infusion. 200-250 g male Sprague-Dawley rats were infused for 48 or $96 \mathrm{~h}$ with $50 \%$ glucose (w/v) or the diluent, $0.45 \%$ normal saline, via an indwelling jugular catheter at $2 \mathrm{ml} / \mathrm{h}$ [18]. Blood for plasma glucose was obtained by tail snipping each morning and the animals were allowed food and water ad libitum. As usual in this model $[18,19]$ the rats were hyperglycaemic for the first $24-72 \mathrm{~h}$ but were euglycaemic by $72-$ $96 \mathrm{~h}$ of infusion. We have previously shown that in this model, the beta-cell mass is selectively increased $50 \%$ as determined by morphometric analysis [19]. Pancreatic RNA was isolated from these rats after 48 or $96 \mathrm{~h}$ of infusion and from weightmatched, normal, untreated rats.

$R N A$ preparation. Total pancreatic and purified isolated islet RNA was prepared in guanidine thiocyanate by the method of Chomczynski et al. [21]. Integrity of the RNA samples was assessed by ethidium bromide staining of the ribosomal bands on agarose/formaldehyde gels.

Northern blots and slot blots. Ten micrograms of total RNA from each experimental animal was electrophoresed on $1.2 \%$ agarose $/ 2.2 \mathrm{~mol} / \mathrm{l}$ formaldehyde surface tension gels [22] and transferred to Nytran nylon membranes for hybridization
(Schleicher \& Schuell, Keene, N.H. USA). For simultaneous quantification of multiple samples, $10 \mu \mathrm{g}$ of total RNA was applied to Nytran membranes using a Millipore Slot Blotter (Millipore, Bedford, Mass., USA).

cDNA probes. The Reg gene probe was a 490-bp fragment encompassing nucleotides $200-690$ of the Reg sequence and was generously provided by C.Newgard (University of Texas Southwestern Health Science Center, Dallas, Tex., USA). This probe hybridized to an mRNA of $0.9 \mathrm{~kb}$ in length as previously reported [8]. The amylase gene probe was an $0.8 \mathrm{~kb}$ Eco R1 cDNA fragment isolated from a mouse pancreas library and was generously provided by M. Meisler (University of Michigan, Ann Arbor, Mich., USA). The probe hybridized to an amylase message of $1.6 \mathrm{~kb}$ [23]. All cDNA probes were labelled with (alpha $\left.{ }^{32} \mathrm{P}\right)$ dCTP $(3000 \mathrm{Ci} / \mathrm{mmol}$, Amersham, Arlington Heights, Ill., USA) with a random-hexanucleotide priming kit (Boehringer Mannheim, Indianapolis, Ind., USA).

Northern blot analysis. Hybridization with DNA probes was performed at $45^{\circ} \mathrm{C}$ for $16 \mathrm{~h}$ in a solution containing $50 \%$ formamide, $5 \times \mathrm{SSC}$ (final concentration $=750 \mathrm{mmol} / 1 \mathrm{NaCl}$, $75 \mathrm{mmol} / \mathrm{l}$ sodium citrate), $20 \mathrm{mmol} / \mathrm{l}$ sodium phosphate buffer (pH 6.7) $2 \times$ Denhardt's solution (final concentration $=0.04 \%$ bovine serum albumin, $0.04 \%$ Ficoll, $0.04 \%$ polyvinylpyrrolidone), $0.2 \%$ sodium dodecyl sulphate, $5 \%$ dextran sulphate, and denatured salmon sperm DNA $(100 \mu \mathrm{g} /$ $\mathrm{ml}$ ) and labelled probe $\left(2.5-5,0 \times 10^{6} \mathrm{cpm} / \mathrm{ml}\right)$. Following hybridization, the filters from both the Northern and slot blots were washed twice in $2 \times \mathrm{SSC}, 0.1 \% \mathrm{SDS}$, for $15 \mathrm{~min}$ at room temperature; twice in $1 \times \mathrm{SSC}, 0.1 \% \mathrm{SDS}$ for $30 \mathrm{~min}$ at room temperature and once in $0.1 \times \mathrm{SSC}, 0.1 \% \mathrm{SDS}$ for $60 \mathrm{~min}$ at $45^{\circ} \mathrm{C}$. The filters were exposed to X-ray film for $1-3$ days and the results were quantified on a computerized densitometer (Molecular Dynamics, Sunnyvale, Calif., USA).

\section{Results}

Changes in pancreatic Reg/PSP mRNA levels were investigated at 1,2,3,7 and 14 days following a $90 \%$ Px or sham surgery by slot blot RNA analysis. One day after Px, levels of Reg/PSP mRNA expression are greatly increased relative to levels seen in normal, unoperated animals and were significantly elevated at 1, 2 and 3 days. Surprisingly, a smaller increase is also found in the control, sham-operated rats at 1 and 2 days (Fig. $1 \mathrm{~A}$ ). By densitometry, the Reg/PSP mRNA levels were increased five fold in the Px rats by 2 days after surgery and gradually decreased to levels found in unoperated rats by 14 days (Fig.1B). In sham-operated rats, Reg/PSP mRNA levels were increased four fold by 1 day after sham surgery, and decreased to unoperated control levels by 7 days. The increase in Reg/PSP mRNA in shamoperated animals was unexpected since the animals underwent an abdominal laparotomy with lysis of pancreatic mesenteric connections, similar to the procedure in Px rats, but no pancreatic tissue was removed or injured. To further investigate this observation, mRNA was prepared from additional control rats treated to mimic individual steps in the sham surgery and assayed by Northern blotting. 


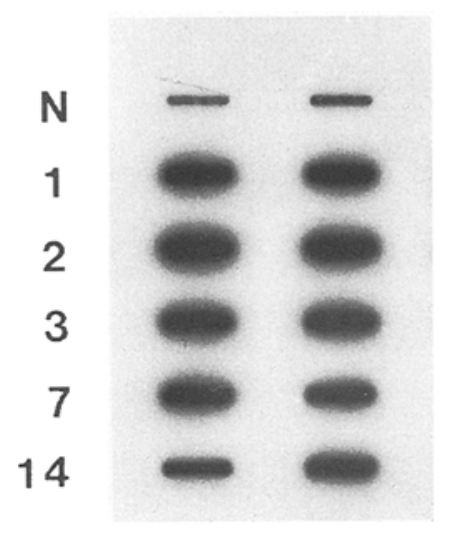

A $\mathrm{PX}$

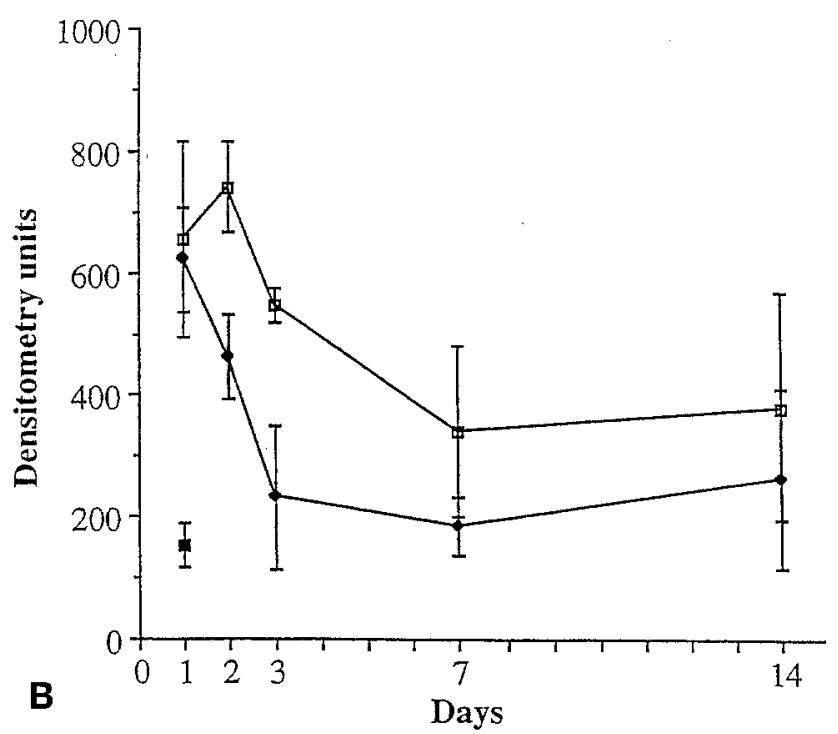

Fig. 1A. Representative slot blot from two animals at each time point. A rapid induction of Reg/PSP mRNA was found in both Px and sham rats, $(\mathrm{N})=$ normal, non-operated weightmatched control rats, (top row); $(\mathrm{Px})=90 \%$ pancreatectomized rats $1,2,3,7$ and 14 days after surgery; $(\mathrm{S})=$ sham-operated rats at 1, 2, 3, 7 and 14 days after surgery, $n=2$. The highest levels of expression were seen at 1-2 days and decreased gradually, approaching normal levels by 14 days $\mathbf{B}$. Time course of Reg/PSP gene expression. The slot blots were quantified densitometrically. Data are mean \pm SEM of values obtained from three animals at each time point. Reg/PSP gene expression in the Px rats $(\square)$ and sham rats $(\bullet)$ was significantly higher $(p<0.01$, unpaired Student's $t$-test) in the Px rats (1,2,3 days) and in sham rats (1,2 days) compared to the unoperated control ( $\boldsymbol{\square})$. The peak expression in the Px rats occurred 2 days following surgery and was five fold higher than in non-operated rats. The peak expression in the shamoperated rats was 1 day after surgery and was four fold higher than normal. Reg/PSP expression was also significantly elevated $(p<0.05)$ in the Px rats compared to sham rats at 2 and 3 days

A small increase of pancreatic Reg/PSP mRNA was even observed in control rats, $24 \mathrm{~h}$ after a single intraperitoneal injection of sodium amytal anaesthetic. Furthermore, with progressively more invasive procedures, including abdominal laparatomy, and la-
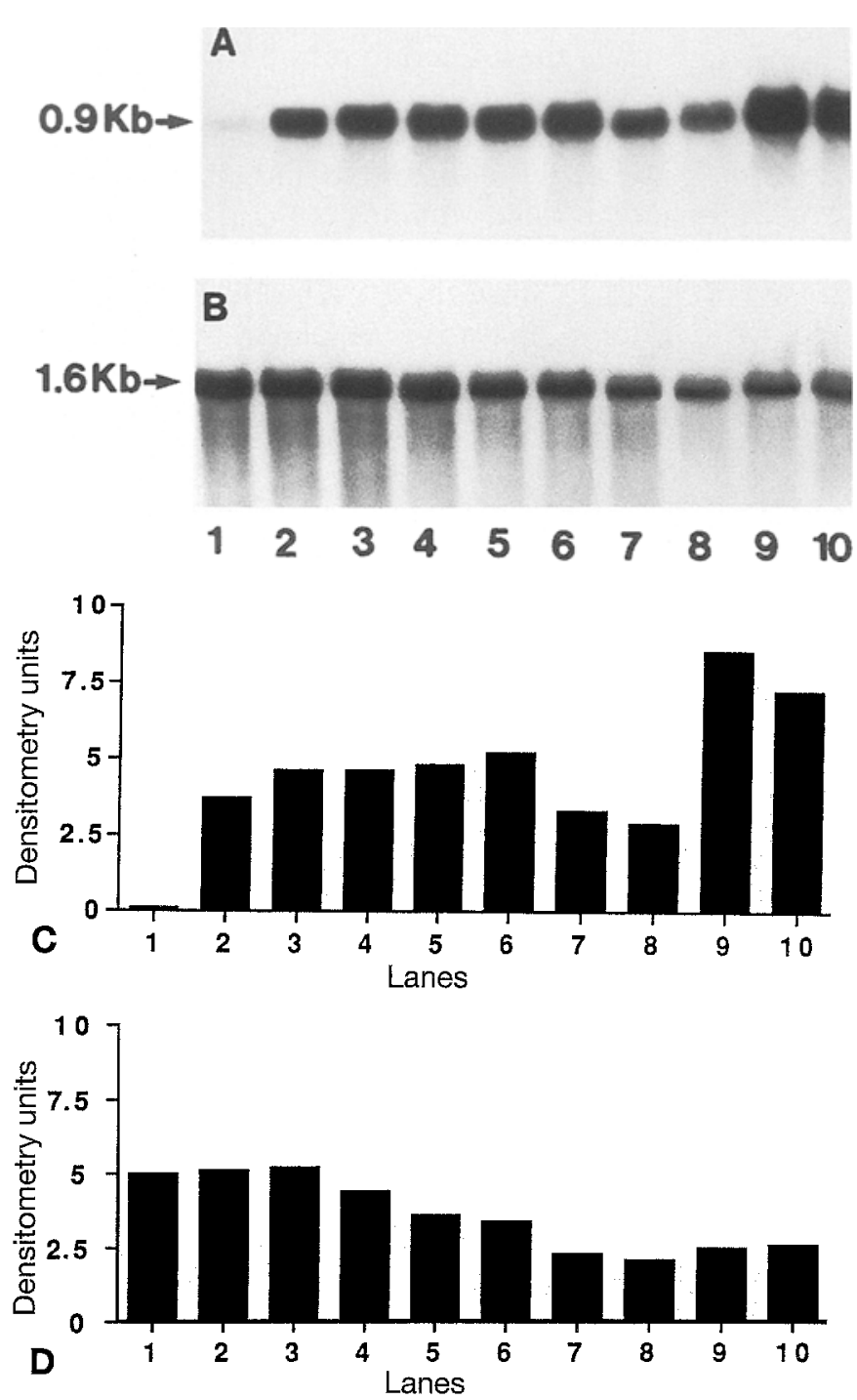

Fig. 2A-D. Reg/PSP gene expression after Px and sham surgery. A representative Northern blot of pancreatic RNA samples hybridized to the Reg/PSP gene probe $(0.9 \mathrm{~kb}$ message). A baseline level of Reg/PSP gene expression is found in normal, non-operated, weight-matched control rats (Lane 1). Reg/PSP gene expression can be induced within $24 \mathrm{~h}$ after a single intraperitoneal injection of sodium amytal (Lane 2), or surgical laparatomy (Lane 3), or laparatomy and lysis of mesenteric-colonic adhesions (Lane 4). The highest levels of induction are seen at 1,2 and 3 days after a 90\% Px (Lanes 8, 9, 10) but a similar but less marked pattern is found at 1,2 and 3 days after sham surgery (Lanes 5,6,7), $\mathbf{C}$ shows the densitometry values from each lane $\mathbf{B}$ The filter was stripped and reprobed with a rat amylase cDNA probe $(1.6 \mathrm{~kb}$ message), D the densitometry values for the amylase probe. Pancreatic amylase expression was not increased in the samples where $\mathrm{Reg} / \mathrm{PSP}$ was induced. The amylase mRNA levels were decreased in the Px rats in contrast to the large increase in Reg/ PSP mRNA levels

parotomy with lysis of mesenteric-colonic adhesions, Reg/PSP mRNA levels were similarly increased (Fig. 2 A, C). To determine if this increase in Reg/ PSP mRNA was part of a generalized increase in exocrine transcription, the filters were then stripped and 

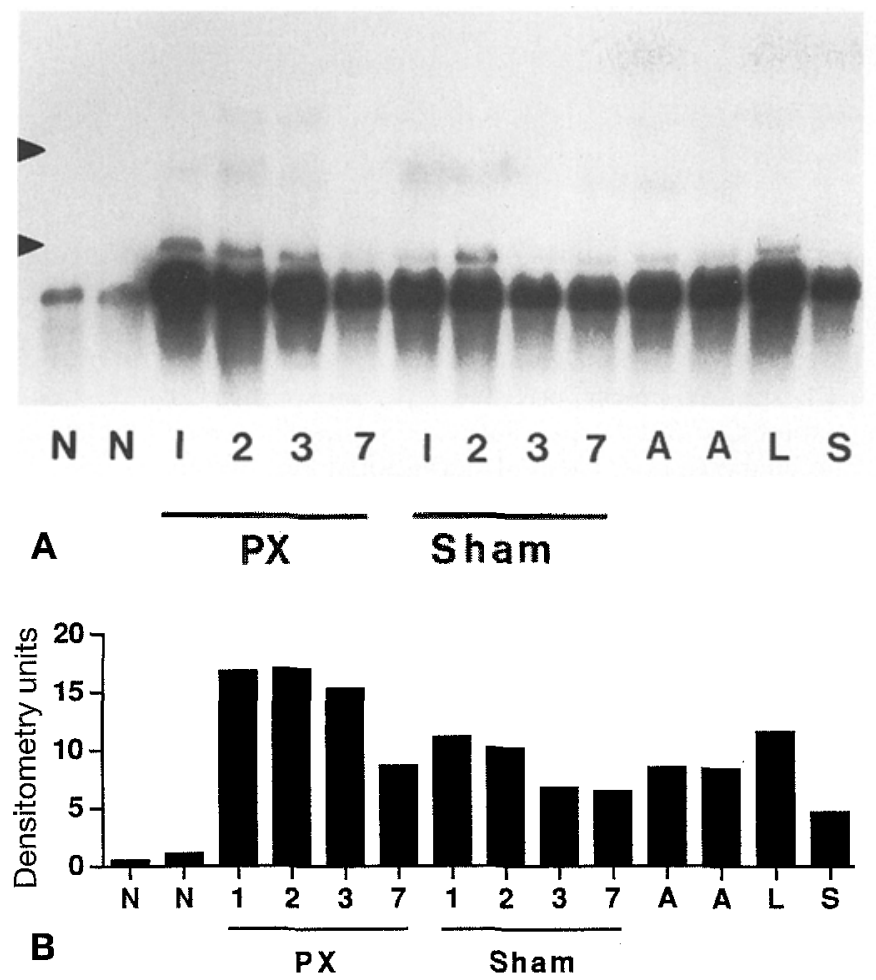

Fig. 3 A. Northern blot of pancreatic RNA samples. Arrowheads indicate position of the $28 \mathrm{~S}$ and $18 \mathrm{~S}$ ribosomal bands. Each lane contains $10 \mu \mathrm{g}$ of total pancreatic RNA hybridized with the Reg/PSP cDNA probe ( $0.9 \mathrm{~kb}$ message). Rats subjected to moderate stress (S) have a non-specific induction of the pancreatic Reg/PSP gene which is higher than normal rats (N) but less than Px or sham (S) rats at 1,2,3 and 7 days after surgery. Rats given an intraperitoneal injection of sodium amytal (A) or abdominal laparatomy (L) show non-specific enhancement of expression. B shows the densitometry value of each lane

reprobed with a pancreatic amylase cDNA probe. In contrast to the pattern of Reg/PSP mRNA induction, expression of the amylase gene was not increased in control samples but was decreased in the Px rats (Fig. 2B,D). The decrease in amylase mRNA is consistent with previous studies where amylase mRNA is reduced in diabetic animals [23]. Thus, pancreatic Reg/PSP mRNA levels were specifically induced under different conditions.

A common variable among the sham treatments tested was a moderate degree of stress on the rats created by handling and intraperitoneal injections or anaesthesia. Comparing the normal, unstressed rats with other controls, a small induction in Reg/PSP mRNA found in the normal, stressed rats may account for some of the increase in mRNA observed in sham rats (Fig. 3).

Since the increase in Reg/PSP mRNA levels correlates with a significant growth of both exocrine and endocrine tissue in the $90 \%$ Px model $[16,17]$, Reg/ PSP mRNA expression was analysed in a model specific for beta-cell growth. Normal rats were infused with $50 \%$ glucose for $96 \mathrm{~h}$. These rats became mar-
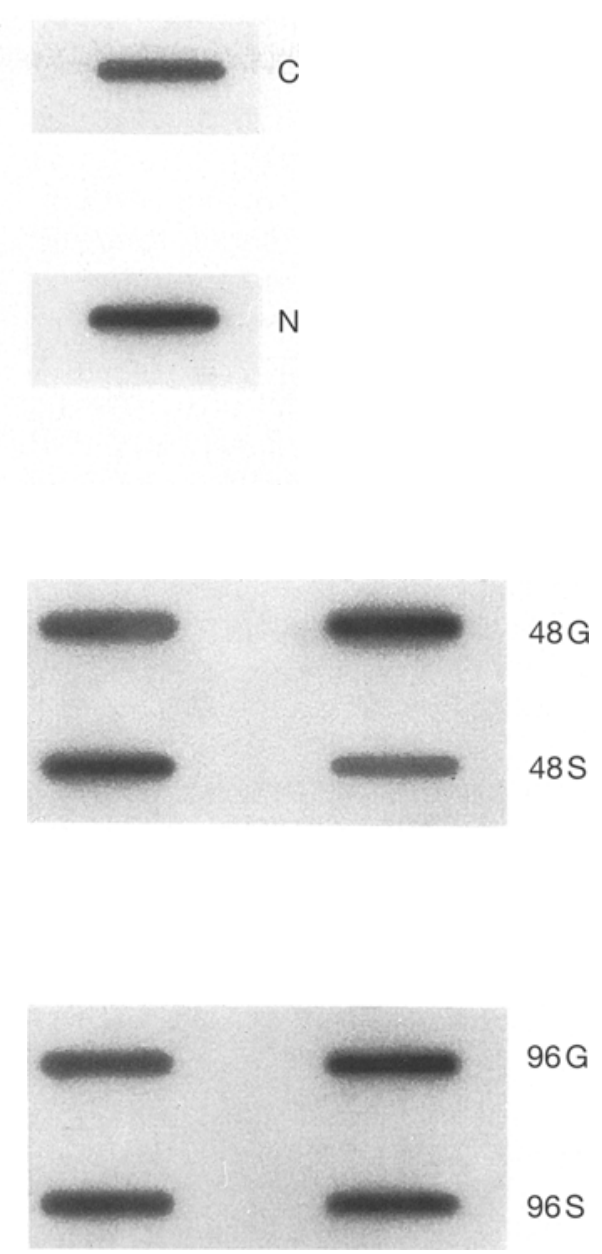

Fig. 4. Slot blot of pancreatic Reg gene expression following glucose or $0.9 \% \mathrm{NaCl}$ infusions for $96 \mathrm{~h}$. Total RNA (10 $\mu \mathrm{ng})$ was applied to each slot. Reg/PSP gene expression was unchanged from levels in weight-matched control rats (C), catheterized but non-infused rats $(\mathrm{N})$ and catheterized rats infused for $48 \mathrm{~h}$ with $50 \%$ glucose $(48 \mathrm{G})$ or $0.9 \% \mathrm{NaCl}$ (48S) and for $96 \mathrm{~h}$ with $50 \%$ glucose $(96 \mathrm{G})$ or $0.9 \% \mathrm{NaCl}(96 \mathrm{~S})$

kedly hyperglycaemic by $24 \mathrm{~h} \quad(564 \pm 23 \mathrm{mg} / \mathrm{dl}$ $(31.3 \pm 1.3 \mathrm{mmol} / 1$ vs saline-infused, $134 \pm 7 \mathrm{mg} / \mathrm{dl}$, $7.4 \pm 0.4 \mathrm{mmol} / \mathrm{l})$ but glucose levels were normalized by $96 \mathrm{~h}$ of infusion, consistent with our previous observations $[18,19]$. Previous morphometric analysis has demonstrated that while the beta-cell mass is selectively increased by $50 \%$, there is a decrease in the exocrine mass. Slot blot analysis of pancreatic RNA from these rats demonstrated no difference in Reg/ PSP gene expression among glucose-infused, salineinfused, and untreated rats (Fig.4).

\section{Discussion}

The role of Reg/PSP in pancreatic islet regeneration has been controversial. In this study, we report a rapid induction of pancreatic Reg/PSP expression within $24 \mathrm{~h}$ after sham or Px surgery which returns to levels equivalent to non-operated rats by 7 or 14 days, 
respectively. While this increase in Reg/PSP mRNA can be correlated in time to a significant regenerative growth of beta cells and exocrine tissue after Px, $\mathrm{Reg} / \mathrm{PSP}$ induction is also found in pancreatic tissue of sham rats that do not increase exocrine or betacell mass. Although specific induction of Reg/PSP mRNA in islets after $90 \%$ Px cannot be totally excluded, we did not find any Reg/PSP protein in islets after Px by immunohistochemistry (data not shown). Furthermore, in a non-surgical model of pancreatic growth, the chronic glucose infused rat, Reg/PSP mRNA levels were not increased even though the beta-cell mass has been shown to increase by $50 \%$ during infusion [19]. Therefore, we found no correlation between Reg/PSP mRNA induction and pancreatic or beta-cell growth.

Originally, the Reg/PSP gene was cloned as a result of its highly expressed RNA in regenerating islets [1]. However, Reg/PSP normally appears to be expressed in the exocrine pancreas $[8,10,11]$. A possible explanation for this discrepancy as suggested by Miyaura et al. [8] was that the original islet cDNA library from which the Reg gene was cloned was significantly contaminated with exocrine tissue as demonstrated by the frequency of amylase-positive clones. Evidence of Reg/PSP protein localization in beta-cells was shown by immunostaining several weeks after partial pancreatectomy and daily nicotinamide injection [12]. Unlike the study by Terazano et al. [12], we did not use daily nicotinamide injections after Px, and thus it is also conceivable that nicotinamide has a specific effect on Reg/PSP induction.

A lack of correlation between Reg/PSP mRNA levels or protein with beta-cell growth is consistent with previous observations that Reg/PSP is not immunohistochemically detectable in islet-cell tumours $[24]$, insulinomas $[1,13]$ and in all but one case of human nesidioblastosis [13].

Recently, Reg/PSP gene expression was reported to be increased in cultured rat islets after stimulation with multiple factors. The increase in Reg/PSP expression in islets was correlated with increased thymidine uptake by the cells [9]. However, the cell types responsible for the increased Reg/PSP expression as well as those with increased thymidine uptake were not identified and may not be the same cells. Previously, non-endocrine cells within islets have been clearly shown to take up thymidine at a greater rate than islet endocrine cells [25].

In this study, we have also found that pancreatic Reg/PSP mRNA can be induced under conditions not associated with pancreatic growth. The mechanism for this induction is not known. Pancreatic exocrine secretion is known to be regulated by both neural and hormonal mechanisms and responses to stress, anaesthesia and laparotomy may be mediated by glucocorticoid receptors which have been de- scribed in exocrine pancreas [26]. Thus, it is unlikely that Reg/PSP is a beta-cell specific growth factor even though the function of this important pancreatic gene is still not known.

Acknowledgements. We thank Mr. C. Cahill for his work with the photographic reproductions, and Ms. L. Bumbalo for her help with the glucose infusions. This work was supported by grants from the National Institutes of Health (DK 35449, DK 44523, DK 36836, DK 38543), a Mental Retardation Center Grant HD 18655 to Children's Hospital, and a Juvenile Diabetes Foundation Grant. F.E. S. was supported by a Juvenile Diabetes Foundation International Fellowship, 390248.

\section{References}

1. Terazono K, Yamamoto H, Takasawa S et al. (1988) A novel gene activated in regenerating islets. J Biol Chem 263: 2111-2114

2. Unno M, Yonekura H, Nakagawara K et al. (1993) Structure, chromosome localization, and expression of mouse reg genes, reg I and reg II. J Biol Chem 268: 15974-15982

3. De Caro AM, Adrich Z, Fournet B et al. (1989) N-terminal sequence extension in the glycosylated forms of human pancreatic stone protein. The 5 oxoproline $\mathrm{N}$-terminal chain is 0 -glycosylated on the 5 th amino acid residue. Biochim Biophys Acta 994: 281-284

4. Watanabe T, Yonekura H, Terazono K, Yamamoto H, Okamoto $H$ (1990) Complete nucleotide sequence of human reg gene and its expression in normal and tumoral tissues. J Biol Chem 265: 7432-7439

5. Gross J, Carlson RI, Brauer AW, Margolies MN, Warshaw AL, Wands JR (1985) Isolation, characterization and distribution of an unusual pancreatic human secretory protein. J Clin Invest 76: 2115:2126

6. Giorgi D, Bernard J-P, Rouquier S, Iovanna J, Sarles H, Dagorn J-C (1989) Secretory pancreatic stone protein messenger RNA. J Clin Invest 84: 100-106

7. Bernard JP, Adrich Z, Montalo G et al. (1991) Immunoreactive forms of pancreatic stone protein in six mammalian species. Pancreas 6: 162-167

8. Miyaura C, Chen L, Appel M et al. (1991) Expression of reg/PSP, a pancreatic exocrine gene: relationship to changes in islet $\beta$-cell mass. Mol Endocrinol 5: 226-234

9. Francis PJ, Southgate JL, Wilkin TJ, Bone AJ (1992) Expression of an islet regenerating (reg) gene in isolated rat islets: effects of nutrient and non-nutrient growth factors. Diabetologia 35: 238-242

10. Yamadera K, Moriyama T, Makino I (1990) Identification of immunoreactive pancreatic stone protein in pancreatic stone, pancreatic tissue, and pancreatic juice. Pancreas 5: 255-260

11. Shimosegawa T, Koizumi M, Moriizumi S, Okamoto $H$, Toyota T (1990) Immunohistochemical demonstration of reg protein in the normal rat and human pancreas. Pancreas 5: 731 (Abstract)

12. Terazano K, Uchiyama Y, Ide M et al. (1990) Expression of reg protein in rat regenerating islets and its co-localization with insulin the beta-cell secretory granules. Diabetologia 33: $250-252$

13. Banister SH, Cole DR, Sarsfield P et al. (1992) Reg protein localization in pancreatic tissue from patients with nesidioblastosis and insulinoma. Diabetes 41: 161 (Abstract)

14. Senegas-Balas FO, Figarella CG, Amouric MA, GuyCrotte OM, Bertrand CA, Balas DC (1991) Immunocyto- 
chemical demonstration of a pancreatic secretory protein of unknown function in the human duodenum. J Histochem Cytochem 39: 915-919

15. de la Monte SM, Ozturk M, Wands JR (1990) Enhanced expression of an exocrine pancreatic protein in Alzheimer's disease and the developing human brain. J Clin Invest 86: 1004-1013

16. Bonner-Weir S, Trent DF, Weir GC (1983) Partial pancreatectory in the rat and subsequent defect in glucose-infused insulin release. J Clin Invest 71: 1544-1553

17. Brockenbrough JS, Weir GC, Bonner-Weir S (1988) Discordance of exocrine and endocrine growth following $90 \%$ partial pancreatectomy in the rat. Diabetes $37: 232-$ 236

18. Leahy JL, Cooper HE, Deal DA, Weir GC (1986) Chronic hyperglycemia is associated with impaired glucose influence on insulin secretion. A study in normal rats using chronic in vivo glucose infusions. J Clin Invest 77: 908-915

19. Bonner-Weir S, Deery D, Leahy JL, Weir GC (1989) Compensatory growth of pancreatic B-cells in adult rats after short-term glucose infusion. Diabetes 38: 49-53
20. Bonner-Weir S, Baxter LA, Schuppin GT, Smith FE (1993) A second pathway for regeneration of adult exocrine and endocrine pancreas, a possible recapitulation of embryonic development. Diabetes 42: $1715-1720$

21. Chomczynski P, Sacchi N (1987) Single-step method of RNA isolation by acid guanidinium thiocyanate-phenolchloroform extraction. Anal Biochem 162: 156-159

22. Rosen KM, Lamperti ED, Villa-Komaroff L (1990) Optimizing the Northern blot procedure. Biotechniques 8: $398-403$

23. Osborn L, Rosenberg MP, Kelly SA, Meisler MH (1987) Tissue-specific and insulin-dependent expression of a pancreatic amylase gene in transgenic mice. Mol Cell Biol 7: 326-334

24. Newgard CB, Hughes S, Chen L, Okamoto H, Milburn JL (1989) The reg gene is preferentially expressed in the exocrine pancreas during islet regeneration. Diabetes 38: 49 (Abstract)

25. De Vroede MA, In't Veld PA, Pipeleers DG (1990) Deoxyribonucleic acid synthesis in cultured adult rat pancreatic B cells. Endocrinology 127: 1510-1516

26. Yoon H-I, Lee P-C (1992) Autologous regulation of pancreatic glucocorticoid receptors in suckling rats. Pancreas 7: 226-232 